\title{
Orwell's Homage to Catalonia in Catalan and Spanish translation
}

\author{
Josep Marco*
}

Department of Translation and Communication, Universitat Jaume I, Castelló, Spain

\begin{abstract}
This article examines the Catalan and Spanish translations of George Orwell's Homage to Catalonia published by Ariel in 1969 and 1970 (respectively) from two perspectives: that of the censorship files preserved at the Archivo General de la Administración in Alcalá de Henares, and that of the published translations. First, relevant information is provided on the setting in which those translations were published, as regards institutionalised censorship and the reception of Orwell's work under Franco. This is followed by analysis of data from the files and from the texts. Such an analysis allows us to determine in the present case that, whereas the censor's injunctions were mostly followed by the publisher, advantage was also taken of the censor's hesitations to preserve as much of the source text's memorial content as possible in the translations. Results of the analysis are finally linked with general concepts at the interface of translation and memory studies. If translators and publishers are seen as secondary witnesses in accounts of traumatic events, then censors may be regarded as tertiary witnesses, and censored texts as sites of dialectic tension between memory and forgetting.
\end{abstract}

Keywords: George Orwell; Homage to Catalonia; Catalan translation; Spanish translation; censorship; memory and forgetting

\section{The Orwell syndrome}

George Orwell's Homage to Catalonia is undoubtedly one of the cornerstones on which representations of the Spanish Civil War were built in the United Kingdom. Berga (2001, p. 65) dubs it 'the most respected eyewitness account of that war.' Bush (2015) goes even further and claims that Orwell's is the account of this war, on the ground of what he refers to as the Orwell syndrome - the alleged attitude of 'suspicion towards what is foreign and indifference towards what is different among the [English-speaking] educated elites' (2015, p. 24). In the particular case of Orwell and the Spanish Civil War, it concerns 'the fact that his account becomes the touchstone, the canonical text that must be read by any Englishspeaker who wants to know something about the Spanish Civil War, for whatever reason' (Bush, 2015, p. 25). ${ }^{1}$ The reason for this partiality lies in the fact that Orwell is, to the educated elites just mentioned, one of their own, no matter how radical his vital and political standpoint may seem. And the effect of this partiality is seen by Bush as simplistic and reductionist, as well as detrimental to translation, insofar as 'it cancels and replaces other, complementary, more nuanced writings in the languages of the Iberian peninsula which ought to be translated' (ibid.). But what about its reception in Spain, i.e. by speakers of those languages of the Iberian peninsula Bush refers to? After all, it is members of the target community that are most closely and deeply concerned by Orwell's account in terms of historical memory. As argued by historian Pierre Vilar (quoted by Berga, 2001, p. 56): 'The

\footnotetext{
*E-mail: jmarco@uji.es
} 
image of a country (even when it is inaccurate) which is projected by a widely read eyewitness (even if his own reasons are arguable) becomes part of the history of that country.'

This is where translation comes into play. And, since the earliest translations in Spain of Orwell's memoir of the war were published under Franco's regime, reception of the book via translation cannot be dissociated from censorship affairs. There are three previous studies on the story of Homage to Catalonia in Spanish and Catalan, including the dealings of publishers with the censorship office: Lázaro (2001 and 2005) and Ripoll (2016). Lázaro (2001) looks at both the censorship files on record at the Archivo General de la Administración (AGA) in Alcalá de Henares and the published translations vis-à-vis Orwell's source text, even if the Catalan translation receives remarkably less attention than its Spanish counterpart. In his later study (Lázaro, 2005), only censorship files are taken into account. Ripoll looks at both censorship files and translations, but again the Spanish translation is analysed in much more detail than the Catalan. In the present study I will draw on Lázaro's and Ripoll's work and attempt to enrich it by looking carefully both at censors' reports and the Catalan and Spanish published translations (section 4). But before the texts themselves hold centre stage, some contextualisation will be in place as regards censorship under Franco's regime (section 2) and the reception of Orwell's work in Spain (section 3). Section 5 will act as a conclusion in which the particular case of Homage to Catalonia and its Catalan and Spanish translations are linked with more general concepts at the interface of translation and memory studies.

\section{Censorship under Franco's regime}

Franco's regime institutionalised censorship in 1938, even before the Civil War was over. According to Abellán (1980, p. 15), the censorship system was 'geared towards establishing the primacy of truth and disseminating the general doctrine of the Movimiento.' The earliest legal provisions issued during the war were supposed to be provisional, but in fact the 1938 Ley de Prensa remained in force until as late as 1966. The general criteria ruling censors' behaviour fell under three major categories, as remarked by several scholars (Abellán, 1980, p. 112; Cisquella et al., 1977, p. 22; Meseguer, 2015, p. 110): politics, morality and religion. They were spelt out by Abellán (1980) as follows: a) criteria underlying the Catholic Church's index of forbidden books; b) critique of the ideology or praxis of Franco's regime; c) public morality; d) clash with the tenets of Nationalist historiography; e) critique of the civil order; f) apology of Marxist or non-authoritarian ideologies (ideologies which, from the point of view of Franco's supporters, had been defeated in the war); g) any work showing hostility towards Franco's regime must not be authorised.

Meseguer (2014) talks about a three-tiered hierarchy in the censorship system, consisting of lectores ('readers'), dictaminadores ('those issuing a verdict') and responsables ('those responsible for censorship policy’). Most authors (Abellán, 1980; Meseguer, 2014, etc.) also distinguish between two types of censorship: institutional censorship, or censorship proper, i.e. the set of modifications, suppressions and additions enforced by the censorship office, and self-censorship, performed consciously or unconsciously by the author/translator or the 
publisher to adjust the text to the censor's requirements. The impact of self-censorship on the creative process is extremely difficult to gauge because in most cases it leaves no trace.

The behaviour of the censorship office was sensitive to external circumstances and did not remain unaltered. Broadly speaking, two main periods are usually identified: 1938-1966 and 1966-1978. The first period, in the wake of Serrano Suñer's Ley de Prensa, was characterised by strict criteria. All publications had to be submitted for compulsory previous censorship. The watershed between the two periods was Fraga Iribarne's Ley de Prensa e Imprenta, issued in 1966 (see, for instance, Cisquella et al., 1977; Abellán, 1980; Meseguer, 2014). The censorship measures introduced by this law were ostensibly less strict, along the lines laid by the Regime's allegedly more open policies (aperturismo); however, in fact they proved to be equally repressive but more Machiavellian in its application. Previous censorship was abolished and the publisher could choose between two possibilities: voluntary consultation (whereby the censorship office granted permission for publication or otherwise) or legal deposit (according to which six copies of the publication were submitted). The latter option was extremely dangerous to the publisher's interests, as the authorities preserved the right to seize an entire edition if the book was deemed unacceptable for the public. This meant that a publisher was liable to suffer important economic losses if they did not make sure that the book complied with censorship standards.

\section{Orwell's work in Spain under Franco}

The reception of Orwell's well-known satires of totalitarianism (Animal Farm and 1984) in Spain has been studied by such authors as Berga (1984), Lázaro (2001, 2005), Meseguer (2014) and Ripoll (2016). Those works did not encounter serious opposition from the censorship office, at least in political terms, because they were construed as diatribes against Communism and, more particularly, Stalinism - not against totalitarianism of any description. They were accordingly regarded as useful propaganda tools. Meseguer (2015) identifies strategies of deletion, substitution, addition and rewriting in the Spanish translations that were prompted by the censors' reports and geared to facilitating that particular reading. This consideration certainly outweighed the fact that the author was a well-known left-wing writer who had fought in the Civil War on the Republican side and could obviously be dubbed 'hostile' to Franco's regime. The importation of an Argentinian edition of Animal Farm (Rebelión en la granja) was authorised in 1951, and permission was likewise granted for a Catalan edition in 1963. The censor raised no objection whatsoever and described the book as 'an amusing satire about dictatorship' (Ripoll, 2016). Similarly, a Spanish translation of 1984 was authorised in 1951 (after a frustrated attempt) and published in 1952; the objections raised by the censor had to do not with politics but with morality (treatment of sex). A Catalan translation was published in 1963.

However, as explained by Lázaro (2001, p. 75), the case was otherwise with Homage to Catalonia - an account of Orwell's experience of the Spanish Civil War, where he fought in the POUM militias on the Aragón front, first in Alcubierre and then near Huesca. While he was on the front, his wife remained behind in Barcelona, where he witnessed the events of 
May 1937 when he was on temporary leave. His account of military life is peppered with his own views on the conflict and the internecine struggles among supporters of the Republic. In this respect, he refers to the suppression of the POUM by the Communists in power, the imprisonment of POUM members and the murder of Andreu Nin, its leader. It must have seemed a chimera to all publishing houses to try and circulate a translation of Homage to Catalonia in Spain during the first decades of Franco's dictatorship, whether imported from Spanish America or commissioned anew. Orwell would have met several of the criteria mentioned by Abellán: apology of Marxist ideologies, hostility towards Franco's regime, critique of the tenets of Nationalist historiography... But in the 1960s, with the new aires aperturistas, it was just conceivable that such a work could make it through censorship control relatively undamaged. Such a conception was based on the fact that the work also featured an account of division within the Republican side, of the way Communists dealt with Trotskyists, whom they saw as their enemies, etc. Publishers could try to cash in on those aspects and they often did.

\section{Homage to Catalonia in Spanish and Catalan}

Even so, the first two attempts by Spanish publishers met with failure. In 1964, Federico Verrié's application to publish the work in Catalan was turned down twice (File 2355-64, Box 21/15171). ${ }^{2}$ Many passages were crossed out in red pencil, and the whole of chapter 5 was to be removed. The first censor acknowledged objectivity in some passages but concluded that the author's sympathies with the red revolutionary movement seeped through his prose. The book was pronounced unfit for publication. The publisher appealed and three new reports were issued by censors Javier Dietta, Manuel María Massa and Manuel Picos. These reports often conflicted with each other - while the first two declared the work publishable, albeit with alterations and suppressions, the third deemed it unfit for publication, as suppressions would expose the Spanish authorities to criticism in the foreign media. The application was accordingly turned down. A second application to publish Orwell's work in Catalan was submitted in 1967 (i.e. when Fraga's Ley de Prensa was already in force), this time by Pòrtic (File 9381-67, Box 21/18570), but it met the same fate. It was turned down on the strength of precedents, and the report added that, if the book was published, it was likely to be seized.

In 1968, only one year after Pòrtic's attempt, an application to publish the work in Spanish was submitted by yet another Catalan publishing house, Ariel (File 10904-68, Box 21/19476). The text submitted for examination was not the English original but an Argentinian edition entitled Cataluña 1937: testimonio sobre la revolución española (Buenos Aires, 1963; translated by Noemí Rosenblatt). The censor, Francisco Fernández Jardón, suggested the following alterations (Lázaro, 2001, p. 79-82; 2005, p. 129-131):

- 'polishing' the book: substituting 'proFranco' for 'Fascist,' 'government-supporters' for 'Loyalists', and 'rising' for 'revolt';

- suppressing 'national' in 'the Catalan national flag'; 'terrible' used to describe Franco's dictatorship; the reference to 'the more naked and developed Fascism of Franco and 
Hitler'; and several comments which presented Franco as 'the puppet of Italy and Germany,' somebody 'tied to the big feudal landlords,' 'an anachronism' supported only by millionaires or romantics;

- including some explanatory footnotes:

- to correct an error having to do with military maps;

- to correct an inaccurate statement about the conquest of Málaga;

- to explain that it was not the Spanish people that had risen against Franco, but leftwing organisations;

- to correct Orwell's statement that Franco attempted to 'restore feudalism';

- to counter the claim that Franco's rising 'had been foreseen for a long time past';

- to deny that what the pro-Fascist press said about atrocities committed by the Republican Government were 'appalling lies';

- to correct another inaccuracy about the shortage of tobacco on the Republican side.

However, curiously enough, once their application had been submitted and met with the injunctions just listed, Ariel changed their mind and decided to publish a Catalan translation first. Even if the source text and the publishing house were the same, this was in fact a new application and was correspondingly assigned a separate file (6605-69, Box 66/03219). Proofs of the Catalan translation by Ramon Folch i Camarasa were sent, the publisher (Alejandro Argullós) claiming in the letter attached that the censor's indications (concerning the previous application for a translation into Castilian Spanish) had been followed, in an attempt to 'limar asperezas' (i.e. 'smooth the text out'). But the censorship office did not agree, pointed out several shortcomings, and turned down the application (July 1969). The publisher appealed, and this time Argullós argued his case carefully indeed. He said that it had long been Ariel's intention to publish a translation of Homage to Catalonia, but they had not dared to attempt it because of the 'carácter polémico' ('controversial nature') of the book. However, now that compulsory previous censorship had been abolished by the 1966 Ley de Prensa, they thought the time had come for Orwell's book to be published 'in our country', especially after 'the release of another famous book, For Whom the Bell Tolls, by Ernest Hemingway.' Publishers - not only Alejandro Argullós - probably kept reading the signs. The censorship office insisted on suppressions and modifications and finally granted 'administrative silence' - a form of passive permission consisting in actually not granting explicit permission but remaining silent (December 1969). The book was published in early 1970.

The same year saw the publication of the Spanish translation of Orwell's work by Carlos Pujol. However, this new translation had to undergo a similar process (File 7399-70, Box 66/05861). Pujol's translation was submitted to the censorship office for voluntary consultation and approved through administrative silence too. Even in this case, the censor's report was thorough and mentioned a crossing-out not taken into account. An intriguing fact about this file is that it contains no copy of the proofs submitted for approval. 
A word is here in place about the particular censor in charge of the Homage to Catalonia case, Francisco Fernández Jardón. According to Sopena (2013, p. 152-153), Jardón was a cultivated judge and a fervent Catholic. He was close to the Asociación Católica Nacional de Propagandistas ('National Catholic Propagandists' Association'), made up of laypersons belonging to the Catholic elites. He held jurisdiction as a judge in Madrid until his retirement in 1973. Sopena (2013, p. 152) claims that ' $[\mathrm{h}] \mathrm{e}$ could read in four foreign languages, correctly summarised the content of works, highlighted their most controversial aspects and confidently voiced his personal opinion.' He seems to have been highly respected by his superiors. But if he ever turned out to be over-indulgent, his verdicts were reversed by those above him. As intimated by Sopena (2013, p. 153), Jardón clung to Francoist orthodoxy but could also be pragmatic and respond to changes in the political atmosphere. He could read in Catalan, even if he was not a native speaker of the language, and, as explained by Sopena, was accordingly chosen to pass verdict on many political and philosophical books submitted by Catalan publisher Edicions 62. Sopena's study reveals that censors were often true scholars, well versed in different fields of the humanities and also attentive to the intellectual climate of their time. This runs counter to the claim made by Cisquella et al. (1977, p. 124) that censors were undereducated ('deficiente formación cultural'). A large body of people usually allows for wide individual differences, but many censors' reports prove that their authors were skilled readers and writers.

The interaction between the publisher and the censorship office, though, does not tell the whole story, as it remains to be seen to what extent the censor's injunctions were obeyed by Ariel. On a first approach, perfect compliance with those injunctions might be taken for granted; but publishers must have been aware of some leeway, if not for open negotiation, at least for silently ignoring some of the cuts and alterations indicated.

Of course, Ariel's prevailing response to censorship was compliance. Thus, the following passage was left untranslated both in the Catalan and the Spanish versions (Orwell, 1989, p. 133-134):

Franco, on the other hand, in so far as he was not merely the puppet of Italy and Germany, was tied to the big feudal landlords and stood for a stuffy clerico-military reaction. The Popular Front might be a swindle, but Franco was an anachronism. Only millionaires or romantics could want him to win.

And, in the following extract, the adjective infamous was dropped, as instructed by the censor (Orwell, 1989, p. 213): 'What clinches everything is the case of Morocco. Why was there no rising in Morocco? Franco was trying to set up an infamous dictatorship, and the Moors actually preferred him to the Popular Front Government!' Both translations (Orwell, 1969, p. 80; Orwell, 1970, p. 105) describe Franco as preparing to 'instaurar una dictadura' ('set up a dictatorship'), with no pre-modifying adjective. These two are examples of plain suppressions. Apart from suppressions, there are also far-reaching modifications that amount to rewriting the text, as in the following passage (Orwell, 1989, p. 189-190): 
For years past the so-called democratic countries had been surrendering to Fascism at every step. The Japanese had been allowed to do as they liked in Manchuria. Hitler had walked into power and proceeded to massacre political opponents of all shades. Mussolini had bombed the Abyssinians while fifty-three nations (I think it was fifty-three) made pious noises 'off'. But when Franco tried to overthrow a mildly Left-wing Government the Spanish people, against all expectation, had risen against him [my emphasis]. It seemed - possibly was - the turning of the tide.

Folch i Camarasa's translation of the sentence underlined, as submitted by the publisher, read as follows: 'Però quan Franco intentà enderrocar un Govern temperadament esquerrà, el poble espanyol, contra totes les previsions, s'havia aixecat contra ell' (page 65 of the proofs submitted for authorisation and still extant at the AGA). That is a faithful translation of Orwell's sentence and requires no back translation. Incidentally, it is consistent with the fact that Folch i Camarasa, as he himself declared in a telephone conversation with Ripoll (2016, p. 45), did not take part in the censoring (or self-censoring) process. He just translated, submitted his translation and was paid for his work; it was the publishing house, then, that revised the translation according to the censor's injunctions. In this case Fernández Jardón had crossed out in red 'Govern temperadament esquerrà, el poble espanyol' ('temperately left-wing Government, the Spanish people') and provided as an alternative 'Govern de Front popular, l'esquerra espanyola' ('Popular Front Government, the Spanish left'). This rendering was adopted both in the Catalan (Orwell, 1969, p. 62) and the Spanish (Orwell, 1970, p. 84) translations. Jardón did not need to argue his correction at this stage, because he had already done so a few months before when Ariel had submitted a copy of the Argentinian edition mentioned above: 'It cannot be claimed that it was the Spanish "people" that opposed the National Movement, but Socialist, Communist and Anarchist workers' organisations, which all but monopolised workers' trade-unionism.' ${ }^{33}$ And, as to the Republican Government's political tendencies: 'The description "mildly left-wing" does not apply to a Popular Front Government that only a few days before the National Movement declared itself, through one of its members, the President, belligerent with the Right. ${ }^{4}$ The three excerpts just reproduced are illustrative of the prevailing tendency of publishers to follow the line of least resistance and to comply with the censor's indications. For a fuller account of suppressions and modifications, see Lázaro (2001, p. 84-87) and Ripoll (2016, p. 43-48) although in both cases more attention is paid to the Spanish than the Catalan translation.

However, publishers were not always so compliant and sometimes displayed an attitude of resistance, of commitment to the meaning of the source text. This attitude is most conspicuous when the preservation of ideologically relevant distinctions is at stake; and what becomes apparent on such occasions is that the publisher takes advantage of any available possibility either to circumvent or to qualify the censor's suggestions, always in an attempt to salvage as much of the source text impact as possible. The censor's corrections bear witness to the fact that he sometimes hesitated or had second thoughts on what exactly must be amended; and the crevices left by those hesitations were often filled in with source text material. Here are a couple of examples. In the first, Orwell describes how the Fascists took 
Málaga without fighting and then the Italian troops fired against the civilian population that had been evacuated (Orwell, 1989, p. 45):

By degrees the whole disgraceful story leaked out - how the town had been evacuated without firing a shot, and how the fury of the Italians had fallen not upon the troops, who were gone, but upon the wretched civilian population, some of whom were pursued and machine-gunned for a hundred miles.

In the Catalan translation submitted for consultation (page 62 of the proofs extant at the AGA), Jardón crossed out the passage 'sinó en la dissortada població civil, els fugitius de la qual havien' ('but on the unfortunate civilian population, the runaways of which had') and replaced it with 'sinó en les milícies populars i en els fugitius de la població civil, que havien' ('but on the popular militias and the runaways of the civilian population, who had'); but then, on second thoughts, and for obvious reasons, he crossed out 'de la població civil' ('of the civilian population') as well. However, this segment was preserved in both the Catalan and the Spanish translations. This is really an ideologically hybrid translation when simultaneously compared to the source text and the censor's amendment. The censor's intention was clearly to substitute the popular militias, who were at that time the bulk of the Republican army, for the civilian population as the target of the Italian troops. The publisher accordingly inserted the militias in the translated text, but managed to preserve the reference to the civilian population who had just evacuated the town being shot by the Fascist troops. This is not a minor point, in terms of the qualitative report handed down to Orwell's Spanish readership in the 1970 s.

A similar case occurs when Orwell is comparing Franco to Hitler and Mussolini and claims $(1989$, p. 190) that

Franco was not strictly comparable with Hitler or Mussolini. His rising was a military mutiny backed up by the aristocracy and the Church, and in the main, especially at the beginning, it was an attempt not so much to impose Fascism as to restore feudalism. This meant that Franco had against him not only the working class but also various sections of the liberal bourgeoisie - the very people who are the supporters of Fascism when it appears in a more modern form.

Jardón must have thought that 'feudalism' did not qualify as just the thing that Franco intended to impose, and accordingly crossed out 'el feudalisme' in the Catalan translation and substituted 'el poder de l'oligarquia' ('the power of the oligarchy') instead (page 65 of the proofs extant at the AGA). But, again, he had second thoughts about the alternative suggested, crossed it out too and replaced it with 'nacionalisme catòlic' ('Catholic nationalism'). The 'power of the oligarchy' must have struck the censor as a more acceptable formulation of the fact that the privileged classes would retain their privileges in the society envisaged by Franco than Orwell's stark 'feudalism'; but he finally chose a more politically correct tag in terms of how the regime presented itself outwardly, i.e. one which, while alluding to two key elements of the regime's established ideology, symptomatically avoided the element of socioeconomic imbalance blatantly present in both 'feudalism' and 
'oligarchy.' As in the previous example, the publisher preserved the censor's first suggestion, not the second, and thus both the Catalan (Orwell, 1969, p. 62) and the Spanish (Orwell, 1970, p. 84) translations claim that Franco's goal was to restore the power of the oligarchy, which comprises the aristocracy and the Church.

As seen above, the censor particularly objected to the use of the Catalan term feixista ('Fascist') as applied to Franco, Franco's troops or Franco's ideology at large. He suggested franquista ('Francoist', 'proFranco') as an alternative. The same applies, of course, to the Spanish translation (fascista). Such a move probably aims to prevent unwelcome associations between European Fascism (largely responsible for the outbreak of World War II and as such already judged and condemned by history) and Francoism, a purely Spanish phenomenon allegedly free from links with the larger picture. But here, as elsewhere, Ariel showed themselves partly compliant with the censor's injunctions, partly rebellious and often creative. Creativity is achieved by means of paraphrases or co-referential expressions, i.e. expressions that refer to the same reality but from a different perspective. Thus, 'Fascist machine-gunners' (Orwell, 1989, p. 30) is rendered as 'los de las ametralladoras' ('those with the machine guns') (Orwell, 1970, p. 67) in Spanish; and 'a Fascist mortar' (Orwell, 1989, p. 39) as 'un morter enemic' ('an enemy mortar') (Orwell, 1969, p. 54) in Catalan.

Ripoll (2016) analysed how the term Fascist was dealt with in Catalan and Spanish translation. The results of her quantitative analysis are shown in tables 1 and 2.

Table 1. Raw and relative frequencies of different translation solutions for the word Fascist in the Catalan translation (adapted from Ripoll, 2016, p. 53).

Table 2. Raw and relative frequencies of different translation solutions for the word Fascist in the Spanish translation (adapted from Ripoll, 2016, p. 53).

Thus, Ariel dared to retain the most straightforward equivalents of Fascist (in the face of the censor's injunction) in over $42 \%$ of the cases in the Catalan translation and in almost $31 \%$ of the cases in the Spanish translation. As a side note, it may be remarked that the Catalan translation avoids rendering 'Fascist' as 'nacionalista' ('Nationalist'), at a time when that term was probably more commonly associated with the Catalan nationalism of vast sectors of anti-Franco resistance in Catalonia than with the established Spanish nationalism, which was so much taken for granted that it was perceived as unmarked.

One might have thought that the censor's objection to the use of Fascist just concerned those occurrences in which it was applied to Franco himself, Franco's troops or the Spanish context, in a more general sense. Using the term to refer to Fascists beyond the Spanish border, in an international setting, must have seemed legitimate even to that censor. However, the publisher was perhaps occasionally over-censorious and substituted 'franquista' for 'Fascist' in contexts where the former term would not apply, as neither Spain nor Franco's plight was concerned. The result of this was plain incoherence, as demonstrated by the following example. At one point Orwell mentions John Strachey and Oswald Mosley, who 
were political associates for some time but then took very different paths, as Strachey sympathised with Communism in the 1930s and Mosley was the main figure behind the British Union of Fascists (1989, p. 246): 'By the same line of argument it could be shown that the English Communist Party is really a Fascist organization, because of Mr John Strachey's one-time association with Sir Oswald Mosley'. Orwell argues ad absurdum that such an association would not warrant considering the English Communist Party a Fascist organisation; but it is still more absurd to present it as a franquista organisation, as the Catalan translation does (Orwell, 1969, p. 171).

Outrageous as the changes prescribed by the censor will always appear to a free spirit, they are no more than what was to be expected in the context of Franco's totalitarian regime. In fact, what is actually surprising in such a context is that so many passages should have remained unaltered which seemed quite likely candidates for suppression or modification. A couple of examples will suffice to illustrate this point, but many more could be brought to bear. The first focuses on the lure of Socialism and the Anarchism of Spaniards. What a classless society might look like was envisioned by Orwell in the Spanish militias; and the 'innate decency' of Spaniards is intimately related to an almost inherent 'Anarchist tinge' (Orwell, 1989, p. 84):

The thing that attracts ordinary men to Socialism and makes them willing to risk their skins for it, the 'mystique' of Socialism, is the idea of equality; to the vast majority of people Socialism means a classless society, or it means nothing at all. And it was here that those few months in the militia were valuable to me. For the Spanish militias, while they lasted, were a sort of microcosm of a classless society. (...) The effect was to make my desire to see Socialism established much more actual than it had been before. Partly, perhaps, this was due to the good luck of being among Spaniards, who, with their innate decency and their ever-present Anarchist tinge, would make even the opening stages of Socialism tolerable if they had the chance.

This is all a far cry from the official doctrine of Franco's regime and the kind of values advocated by it. But even so it was allowed to remain unaltered in the Catalan (Orwell, 1969, p. 111) and Spanish (Orwell, 1970, p. 142-143) translations.

The same applies to the second example, where Franco's dictatorship is presented as a bad solution to Spain's problems. The reference to 'the more naked and developed Fascism of Franco and Hitler' is deleted in both translations, as prescribed by the censor; but in what remains of the passage, Franco's regime is unfavourably compared to other political solutions, such as that embodied by the Republican Government, on two occasions and in unambiguous terms (Orwell, 1989, p. 133):

The only alternatives were an infinitely worse dictatorship by Franco, or (always a possibility) that the war would end with Spain divided up, either by actual frontiers or into economic zones.

Whichever way you took it it was a depressing outlook. But it did not follow that the Government was not worth fighting for as against the more naked and developed Fascism of Franco and Hitler. Whatever faults the post-war Government might have, Franco's regime would certainly be worse. 
Even so, no major shifts are observable in either the Catalan (Orwell, 1969, p. 175) or the Spanish (Orwell, 1970, p. 215) translation. One is left wondering again at the censor's relative permissiveness.

Ripoll (2016: 58-59) also wonders that not more passages were censored in the Catalan and Spanish translations of Orwell's memoir of the Spanish War. This may be due to several reasons. To begin with, it may have been an effect of Fraga's Ley de Prensa - the normative embodiment of a new, more open-minded attitude (aperturismo) on the part of the regime towards cultural matters in general. As suggested by several authors (e.g. Cisquella et al., 1977 , p. 25 and ff.), it must have been a matter of prestige for the regime leaders to project an image of modernity, of moving forward with the times, and to that end the Spanish literary clock, to put it in Casanova's (1999, p. 122) terms, had to be synchronised with that of the literary Greenwich Meridian.

Secondly, relative permissiveness might also have been the result of a condescending attitude, clearly visible in some censors' reports. As explained above, when Federico Verrié applied for permission to publish a Catalan translation of Homage to Catalonia in 1964 (File 2355-64, Box 21/15171 at the AGA), his application was turned down. Then he appealed and three new reports were issued, two of which pronounced the book publishable with significant deletions and modifications. In one of these reports, censor Javier Dietta claims that '[n] owadays, in 1964, after our 25 years of Peace, some things may be allowed to be said that are refuted and even rendered ludicrous and counter-productive for our enemies by time and precisely that Peace.' ${ }^{5}$ And he insists on this point in the report's last sentence: 'And we repeat that Spain is now politically ripe to become acquainted with versions of our war from the other side. ${ }^{6}$ A similar tone is perceived in Manuel María Massa's report: 'I believe that, on account of the Spanish regime's political ripeness, both at home and abroad, its consolidation, and the decline of international Anarchist movements, the work [...] MAY BE AUTHORISED with crossings-out." ${ }^{7}$ The 'political ripeness' of the Regime, then, seems to have been a buzzword among censors when it came to justifying certain decisions. Let us bear in mind, moreover, that the reports just quoted were prior to Fraga's Ley de Prensa.

But, finally, permissiveness might also be put down to mere arbitrariness, as similar deviations from the regime's established values may have met with diverging responses. Some gatekeepers may have been more vigilant than others, and it was not impossible to catch any individual gatekeeper off their guard at any given time. Cisquella et al. (1997, p. 22) even claim that arbitrariness was inherent to the censorship apparatus, as it could not be held accountable to anybody.

Similar factors to those just mentioned may be said to have been at play in another instance of partial forgetting and monitored memorialisation in Spanish letters, invested with lasting significance - that of Federico García Lorca's work. Lorca was murdered by Fascists in August 1936, barely a month after the outbreak of the Civil War. Both the man and his work fell into oblivion during the first years of Franco's regime. But, Delgado (2015, p. 181) argues, after Franco's pact with Eisenhower in 1953 the regime felt the need to 'burnish (...) its international image.' A censored version of Lorca's works was authorised in that same 
year which promoted 'a highly reductive and emphatically depoliticized understanding of the author's corpus' (Delgado, 2015, pp. 181-182). Some ideological aspects of this corpus were carefully omitted, and his work was celebrated by the official press as bringing glory to Spain throughout the world. But of course the value of Lorca's work is inextricably linked with his death and the circumstances surrounding it, which symbolise the deaths of many thousands. It is well known that Spain's transition from Franco's totalitarian regime to democracy was presided over by a pact of silence, which in many respects reaches up to the present. Of course, democratic Spain saw Lorca's work rehabilitated in its integrity; but right-wing parties insisted on keeping the poet and his death apart from his work. Thus, José María Aznar, later to become Spain's Prime Minister, urged his countrymen and countrywomen in 1998, on the one hundredth anniversary of the poet's birth, not to 'bring out old stories because poetry has no ideology, it is beauty and humanity. Spain, today, is called Federico' (Delgado, 2015, p.186). This approach to the past was only adhered to by some, and a few years later the Ley de Memoria Histórica (Law of Historical Memory) was passed by a Socialist government - even though the exhumation of Lorca's body has not taken place yet.

\section{Concluding remarks: Homage to Catalonia, translation and memory}

How does the account provided in the previous section relate to general concepts linking translation and memory? I will argue as a starting point that Homage to Catalonia is, among other things, a memory site - a term coined by Nora (1989) to refer to 'a recognized memorial item of strong and lasting symbolic importance for its community' (Brownlie, 2016, p. 18). (Lorca's case, briefly touched upon in the previous paragraph, is another, even more powerful memory site originating in the Spanish Civil War and its aftermath.) An item becomes a memory site through remediation (Erll, 2009), a phenomenon 'whereby a past event, person or cultural item is repeatedly taken up in diverse medial forms over an extended period of time, for example a historical event is recounted many times over in diverse media and genre' (Brownlie, 2016, p. 17-18). Translation is a form of remediation, and so is film adaptation and it may be here in place to recall that Ken Loach's Land and Freedom (1995) bears some very striking resemblances to Orwell's book. Loach acknowledges it as one of the 'basic texts' (García, 1995) on the Spanish War he read before embarking on the film, and Ehrlicher (2007, p. 288) explains that 'film criticism has repeatedly claimed that this story is based to a large extent on George Orwell's Homage to Catalonia.' Loach's film and its contribution to current debates on historical memory in Spain will be taken up below.

As a memory site, Orwell's memoir of the Spanish war obviously reaches backward to the events narrated. In this respect, the main issue is truthfulness. Berga (2001, p. 54) lucidly notes that "[i]n the battles for narrative the telling becomes ingrained in the tale and in the specific genre of eyewitness accounts the writer has to rely not only on personal experience but also on memory. And memory has shaky foundations.' Brownlie claims (2016, p. 20) in her turn that '[a]utobiographical memory is [...] partly remembered and partly constructed'. To these general objections to memory's trustworthiness must be added the particular doubt cast on Orwell's narrative by French novelist Claude Simon, himself a volunteer in the 
International Brigades during the Spanish War. Berga (2001, p. 57), drawing on previous authors, recounts Simon's skepticism about Orwell's accuracy in the opening chapter of his book and 'his scorn at Orwell's having been trained in a so-called 'Lenin Barracks"', which he regards as 'a fanciful reference by someone writing fiction.' But Orwell's account - Berga (2001, p. 58) goes on - was borne out by Agustí Centelles' ('the Catalan Robert Capa of the civil war') photographs, which 'prove, after all and just in case, that there was a Lenin Barracks in Barcelona and that there was a George Orwell, head and shoulders well above his P.O.U.M. comrades, in those barracks.' However, once doubt in this respect has been dispelled, it remains true that one of the main features of narrativity is selective appropriation (Baker, 2006, in Brownlie, 2016, p. 21), and Homage to Catalonia is undoubtedly a narrative, and a literary one at that. That is made abundantly clear by Berga (2001, p. 55-56), who sees Orwell as 'a very self-conscious writer' and his text as displaying a 'carefully planned stylistic fabric', and concludes (2001, p. 56) that 'he sounds like a reliable witness in his autobiographical writings in as much as he effectively activates the art of fiction.'

But Orwell's memoir also reaches forward to the future. In the English-speaking world, this is effected through reprinting. As seen at the beginning of this study, Homage to Catalonia holds a privileged position among eyewitness accounts of the Spanish Civil War. In Spain, it becomes a memory site mainly through translation. However, since the war led to the establishment of a totalitarian regime that lasted almost forty years, forgetting prevailed over memory until as late as 1969 . The Regime had fabricated its own narrative of the war and its aftermath, and Orwell's account was plainly inconsistent with that narrative and must remain in oblivion. Why then yield to its publication even in 1969? It may be well to recall, in this respect, that translation always occurs in a different context from that of the original and is therefore 'a vehicle of both remembrance and transformation' (Brownlie, 2016, p. 8). In a previous work, Brownlie (2007, p. 139) had already remarked that 'a translation is always less and more than its source text, a representation that creates a particular shaping of the source text', and then referred to the fact that a text from the past 'can be reactivated in translation, and remobilized for specific purposes.' The publishers' purposes are clear enough in our case, and are all on the side of memory; the censors' purpose in ultimately allowing Homage to Catalonia to be published might be said to be twofold: a) to convey the message that the Regime was ripe (as we have just seen) for such a book, and b) even so, to reshape a very influential contesting narrative in order to align it with their own hegemonic narrative.

Another way in which a text that has become a memory site points to the future is through film adaptation. Loach's Land and Freedom (the title itself is highly allusive, as it is a translation of Tierra $y$ Libertad, the name of a magazine published by the Federación Anarquista Ibérica, or Iberian Anarchist Federation) appeared at the right time on the Spanish scene and made a relevant contribution to the ongoing debate on the memory of the war and to a change of attitude in the sphere of film-making and beyond. Film-maker Vicente Aranda (Montero, 1996) claims that in the early 1980s there was a sort of tacit agreement on not making films on the Civil War, and now, he says, with such films as Land and Freedom, 'this 
period in our history resurfaces as if it were something new, but what actually happens is that we have been keeping silent because, for whatever reason, nobody wanted to tackle the issue.' Ehrlinger (2007, p. 292) summarises the impact made by Tierra y Libertad as follows:

it must be acknowledged that Loach's film managed to make the kind of socio-political impact it was seeking. In Spain and other countries it received unusual publicity, which belied the scepticism sparked by the news that yet another film was being shot on the International Brigades issue, almost twenty years after Jaime Camino's La vieja memoria (1978). Eventually, fears that the 'British film-maker's efforts' might be wasted on 'a country of amnesiacs' proved unfounded (Martí, 1994). The film contributed to reversing the 'pact of silence' agreed upon during the Spanish Transition and opening up a new debate on memory. Ken Loach's film was highly instrumental in the turn taken by memory politics from the mid-nineties onward, which was echoed by the media.

Just as translations of Homage to Catalonia into Catalan and Spanish were the site of contesting narratives in the late 1960s, Loach's Land and Freedom helped visualise different attitudes to historical memory in Spain in the mid-1990s. ${ }^{8}$

Brownlie (2016, p. 6) discusses Deane-Cox's (2013) adoption of the concept of secondary witness from Holocaust studies. This term refers to the 'role as an emphatic listener and witness to the oral testimonies' of Holocaust victims. Deane-Cox argues that translators of traumatic narratives can also be regarded as secondary witnesses. And we could go one step further and argue in our turn that, in contexts of censorship, censors are tertiary witnesses no matter how low their degree of empathy may be. The published translations of Orwell's memoir display a dialectic tension between the efforts of secondary witnesses (translators and publisher) to preserve the source text's memorial content relatively undamaged and the tertiary witnesses' (i.e. the censorship apparatus') curious mixture of forgetting (through suppression and modification) and tolerance of that memorial content.

\section{Funding}

This work was supported by the Spanish Ministry of Economy and Competitiveness [FFI2015-68867-P] and Universitat Jaume I [UJI-B2017-58].

\section{Notes}

1. Unless otherwise indicated, all translations from languages other than English are the author's.

2. Records at the Archivo General de la Administración in Alcalá de Henares are identified by file and box numbers.

3. 'No se puede afirmar que haya sido el "pueblo" español quien se opuso al Movimiento nacional, sino las organizaciones obreras socialistas, comunistas y anarquistas que prácticamente poseían el monopolio del sindicalismo obrero.'

4. 'No puede llamarse tibiamente izquierdista a un Gobierno del Frente popular que dias [sic] antes del Movimiento nacional se declaró por boca de uno de sus miembros, el Presidente, beligerante frente a las derechas.'

5. 'Hoy, en 1964, a nuestros XXV años de Paz, puede dejarse que se digan cosas que el tiempo y esa Paz, precisamente, desmiente y hasta hace ridículo y contraproducente para nuestros enemigos.'

6. 'Y repetimos que España tiene suficiente madurez política ya para conocer versiones de nuestra guerra dadas desde el otro lado' (Dietta's emphasis). 
7. 'Creo que, dada la madurez política interior y exterior del Régimen español, su consolidación, y el decaimiento de los movimientos anarquistas internacionales, la obra [...] puede autorizarse con tachaduras' (Massa's emphasis).

8. I am indebted for suggestions to include references to the reception of Land and Freedom in Spain, and of Lorca's work in late Francoism to one of the reviewers of an earlier draft of this article.

\section{Note on contributor}

Josep Marco is currently Professor of Literary Translation and Translation Studies at Universitat Jaume I (Castelló, Spain). His main research interests lie in the areas of the translation of style, corpus-based translation studies, translator education and the history of literary translation into Catalan. He is a member of the COVALT research group. He is also a practising literary translator into Catalan and Spanish.

\section{References}

Abellán, M. L. (1980). Censura y creación literaria en España (1939-1976). Barcelona: Península.

Baker, M. (2006). Translation and conflict: A narrative account. London \& New York: Routledge.

Berga, M. (1984). Mil nou-cents vuitanta-quatre: radiografia d'un malson. Barcelona: Edicions 62.

Berga, M. (2001). Orwell's Catalonia revisited: Textual strategies and the eyewitness account. In A. Lázaro (Ed.), The road from George Orwell: His achievement and legacy (pp. 53-69). Bern: Peter Lang.

Brownlie, S. (2007). Situating discourse on translation and conflict. Social Semiotics, 17(2), 135-150. doi: 10.1080/10350330701311439

Brownlie, S. (2016): Mapping memory in translation. London: Palgrave Macmillan.

Bush, P. (2015). Contra la síndrome d'Orwell (El traductor com a pioner). XXII Seminari sobre la traducció a Catalunya. Traductors, pioners de la cultura (pp. 17-34). Barcelona: Associació d'Escriptors en Llengua Catalana.

Casanova, P. (1999). La República mundial de las Letras. Trans. Jaime Zulaika. Barcelona: Anagrama.

Cisquella, G., Erviti, J. L., \& Sorolla, J. A. (1977). Diez años de represión cultural. La censura de libros durante la Ley de Prensa (1966-1976). Barcelona: Anagrama.

Deane-Cox, S. (2013). The translator as secondary witness: Mediating memory in Antelme's L'espèce humaine. Translation Studies 6(3), 309-323. doi: 10.1080/14781700.2013.795267

Delgado, M. M. (2015). Memory, silence, and democracy in Spain: Federico García Lorca, the Spanish Civil War, and the Law of Historical Memory. Theatre Journal, 67(2), 177-196. doi: 10.1353/tj.2015.0042

Ehrlicher, H. 2007. Batallas del recuerdo. La memoria de la Guerra Civil en Land and Freedom (Ken Loach, 1995) y Soldados de Salamina (David Trueba, 2002). In P. Burkhard \& J. Türschmann (Eds.), Miradas glocales: cine español en el cambio de milenio (pp. 283-305). Madrid: Iberoamericana.

Erll, A. (2011). Travelling memory. Parallax 17(4), 4-18. doi: 10.1080/13534645.2011.605570

García, R. (1995). Ken Loach describe en 'Tierra y libertad' la división del bando republicano en la guerra civil. El País, 6 April 1995. https://elpais.com/diario/1995/04/06/cultura/797119201_850215.html

Lázaro, A. (2001). George Orwell's Homage to Catalonia: A politically incorrect story. In A. Lázaro (Ed.), The road from George Orwell: His achievement and legacy (pp. 71-91). Bern: Peter Lang.

Lázaro, A. (2005). The censorship of George Orwell's essays in Spain. In A. Gomis \& S. Onega (Eds.), George Orwell: A centenary celebration (pp. 121-141). Heidelberg: Winter.

Martí, O. (1994). Un olvido interesado. El País, 12 May 1994, p. 32.

Meseguer Cutillas, P. (2014). La traducción del discurso ideológico en la España de Franco. Murcia. Universidad de Murcia. PhD thesis retrieved from https://www.tdx.cat/handle/10803/132990)

Meseguer, P. (2015). La traducción como arma propagandística: censura de Orwell, Abellio y Koestler en la España franquista. Quaderns de Filologia: Estudis Literaris 20, 107-122. doi: 10.7203/qdfed.20.7532

Montero, M. (1996). Entrevista con Vicente Aranda. La Voz de Asturias, 13 March 1996, p. 67.

Nora, P. (1989). Between memory and history: Les Lieux de Mémoire. Representations 26, 7-24. 
Orwell, G. (1969). Homenatge a Catalunya: un testimoni sobre la revolució espanyola. Trans. Ramon Folch i Camarasa. Barcelona: Ariel.

Orwell, G. (1970). Homenaje a Cataluña: un testimonio sobre la revolución española. Trans. Carlos Pujol. Barcelona: Ariel.

Orwell, G. (1989/1938). Homage to Catalonia. London: Penguin.

Ripoll Gadea, M. (2016). La censura en la traducción de Homage to Catalonia, de George Orwell. Barcelona: Universitat Pompeu Fabra. BA dissertation retrieved from https://repositori.upf.edu/bitstream/handle/10230/27815/Ripoll_2016.pdf?sequence=1

Sopena, M. (2013). «Con vigilante espíritu crítico». Els censors en les traduccions assagístiques d'Edicions 62. Quaderns. Revista de Traducció 20, 147-161. 
Table 1. Raw and relative frequencies of different translation solutions for the word Fascist in the Catalan translation (adapted from Ripoll, 2016, p. 53).

\begin{tabular}{|l|l|l|}
\hline Translation & Examples & Percentage \\
\hline Franquista & 122 & $52.82 \%$ \\
\hline Feixista & 98 & $42.42 \%$ \\
\hline Other & 11 & $4.76 \%$ \\
\hline
\end{tabular}


Table 2. Raw and relative frequencies of different translation solutions for the word Fascist in the Spanish translation (adapted from Ripoll, 2016, p. 53).

\begin{tabular}{|l|l|l|}
\hline Translation & Examples & Percentage \\
\hline Franquista & 130 & $56.28 \%$ \\
\hline Fascista & 71 & $30.74 \%$ \\
\hline Nacionalista & 11 & $4.76 \%$ \\
\hline Other & 19 & $8.22 \%$ \\
\hline
\end{tabular}

